\title{
Serum Cortisol, Calcium and Phosphorus Concentrations in Relation to Incomplete Cervical Dilatation in Goats
}

\author{
Abhishek Bhardwaj ${ }^{1 *}$, M. S. Bawaskar ${ }^{1}$, S. K. Sahatpure ${ }^{1}$, \\ A. P. Gawande ${ }^{1}$, G. R. Bhojne ${ }^{2}$ and D. V. Patil ${ }^{3}$ \\ ${ }^{1}$ Department of Animal Reproduction, Gynaecology and Obstetrics, \\ MAFSU NVC Nagpur, India \\ ${ }^{2}$ Department of Vertinary Clinical Medicine, MAFSU NVC Nagpur, India \\ ${ }^{3}$ Department of AGB, MAFSU NVC Nagpur, India \\ *Corresponding author
}

\section{A B S T R A C T}

\section{Keywords}

Cortisol, Dystocia, Incomplete cervical dilatation, Calcium, Phosphorus

\section{Article Info}

Accepted:

08 June 2020

Available Online:

10 July 2020

\begin{abstract}
The aim of this study was to evaluate the stress and some mineral levels in goats affected with incomplete cervical dilatation. Serum cortisol, calcium and phosphorus concentrations were estimated in incomplete cervical dilatation $(n=6)$ and normal delivered cases $(\mathrm{n}=6)$. The serum cortisol concentration was significantly higher $\quad 179.17 \quad \pm 8.57 \quad \mathrm{nmol} / \mathrm{L} \quad(\mathrm{P}<0.05) \quad$ and $54.17 \pm 3.70 \mathrm{nmol} / \mathrm{L}(\mathrm{P}<0.05)$ in incomplete cervical dilatation and normal cases. There was no significant difference in the concentrations of calcium and phosphorus in incomplete cervical dilatation group i. e. $8.74 \pm 0.54 \mathrm{mg} / \mathrm{dL}(\mathrm{P}<0.05)$ and $6.16 \pm 0.48 \mathrm{mg} / \mathrm{dL} \quad(\mathrm{P}<0.05)$ and in normally delivered goats $9.53 \pm 0.5$ $\mathrm{mg} / \mathrm{dL}(\mathrm{P}<0.05)$ and $6.60 \pm 0.54 \mathrm{mg} / \mathrm{dL}(\mathrm{P}<0.05)$. These results have shown that the stress caused by incomplete cervical dilatation was higher and a non-significant difference was in the calcium and phosphorus levels.
\end{abstract}

\section{Introduction}

Kidding is one of the major event in the life of breeding goats and any difficulty will cause stress to dam. Dystocia due to incomplete cervical dilatation is a common cause of stressor to the animals (Noakes et al., 2001), which may constitute up to $23.7 \%$ (Braun 1997).During the last week, maternal cortisol start increasing and reach to its peak until the process of kidding completes (Adams and Wagner 1970). Some studies supported that the stress is associated with elevated maternal cortisol level in dystocia affected goats and heifers with achievement of a peak at the time of delivery (Hydbring et al., 1999). Incomplete cervical dilatation may occur due to various factors and lead to the cause of dystocia. The serum inorganic phosphorus levels in non-pregnant goats and 3-5 months' 
pregnant goats(Kamel, 1988). Eight healthy Baladi female goats were studied to estimate the changes in biochemical parameters during different physiological stages (Azaband Maksoud 1999). Maternal plasma cortisol was studied by (Strott et al., 1974) in six sheep (2 twin and 4 single pregnancies) and found a 30 -fold increment in the cortisol level. Plasma cortisol concentrations were higher in goats within $30 \mathrm{~min}$ of the starting of transport (Nweet al. 1996). Blood serum Cortisol level concentration increases in case of trauma likewise during the surgical treatments, which reflects as a sign of physiological stress (Fox et al., 1994).

According to many authors, plasma Cortisol levels increases just before the time and during delivery (Varonesi et al., 1978, Baan et al., 2008). Fetus is the source of Cortisol and at the time of parturition the foetal adrenals produces large amount of Cortisol, which may be one of the reason to begin the parturition process (Liggins et al., 1977).

Cervical dilatation is a complex process although there are several studies on the cortisol and biochemical in the normal and dystocia affected animals, but limited studies are on these parameters in goats. Therefore, in the present study, we planned to study serum cortisol, calcium and phosphorus levels in the serum of goats.

\section{Materials and Methods}

These experiments carried out at Teaching Veterinary Clinical Complex, Nagpur and situated at $21.1458^{\circ} \mathrm{N}, 79.0882^{\circ} \mathrm{E}$ and altitude of 311 meters /1020 feet from mean sea level. During the study, the animals were handled, cared, sampled and given treatments without causing them unnecessary pain and approved by the University Committee under the board of studies meeting number BoS/01/2019. For estimating serum cortisol, calcium and phosphorus six goats selected from affected group and six goats were included which had normal kidding.

The blood samples collected at the presentation of animals from the jugular vein after proper cleaning with the scrubbing alcohol in $4 \mathrm{ml}$ clot activator vials. The samples allowed standing for 1 hour at room temperature to allow proper clotting.

Then the samples centrifuged at $3000 \mathrm{rpm}$ for 10 minutes and Serum transferred to $2 \mathrm{ml}$ properly labeled Eppendorf tube and stored at $-20^{\circ} \mathrm{C}$ until biochemical and hormonal analysis. Estimation of serum calcium levels and serum phosphorus was performed with semi-automated biochemical analyzer (Seac STAR-21, Rapid Diagnostics Pvt. Ltd. Model no. S/N 322437) at laboratory of Teaching Veterinary Clinical Complex, Nagpur.

Serum Cortisol was estimated with commercial ELISA kits in total 12 goats (6 with incomplete cervical dilatation \& 6 with normal kidding) at the time of presentation before the administration of any treatment. The values of serum cortisol, calcium and phosphorus expressed as the mean $\pm \mathrm{SE}$, Oneway ANOVA and $\mathrm{P}$ values $<0.05$ considered as statistically significant.

\section{Results and Discussion}

(Table 1.) Shows the values of the mean calcium concentration at the time of presentation of case and before the administration of any treatment was $8.74 \pm$ 0.54 , and $9.53 \pm 0.51 \mathrm{mg} / \mathrm{dl}$ in Group I and II respectively. Values of the mean phosphorus concentration at the time of presentation of case and before the administration of any treatment were $6.16 \pm 0.48$ and $6.6 \pm 0.54$ $\mathrm{mg} / \mathrm{dl}$ in Group I and II respectively. The present findings are in accordance with the (Ismail et al., 2008) who also reported values 
of mean calcium to be $8.5 \mathrm{mg} / \mathrm{dl}$ and ranged between $5.0-17.0 \mathrm{mg} / \mathrm{dl}$. (Varshneyet al. 2018) studied the serum biochemical in the goats and found that normal values of Calcium $(\mathrm{mg} / \mathrm{dl})$ as $8.53 \pm 0.15$ and Phosphorus $(\mathrm{mg} / \mathrm{dL})$ as $5.06 \pm 0.21$, which are in agreement with the present findings. Different findings of serum inorganic phosphorus levels were found to be 5.77 $\mathrm{mg} / \mathrm{dl}$ in non-pregnant goats, and $5.35 \mathrm{mg} / \mathrm{dl}$ by 3-5 months of pregnancy (Kamel1988)andare little higher than the present findings.(Affan et al., 2018) found that the levels of Calcium $(\mathrm{mmol} / \mathrm{L})$ in normal healthy pregnant goats to $2.24 \pm 0.07$ and in pregnancy toxemic to be $1.83 \pm 0.06$ respectively and Cortisol level to be about $17.64 \pm 2.84$ and $108.61 \pm 10.57 \mathrm{ng} / \mathrm{dl}$.

(Tajik et al., 2016) studied 10 pure Raini goats Cortisol levels about $31.66 \pm 2.71 \mathrm{~g} / \mathrm{dl}$. Blood biochemical and hormonal profile of 14 Surti goats and found that cortisol level was higher $3.62 \pm 0.13$ in singlet and $3.34 \pm 0.12$ in double kids (Gamit et al., 2019). In all goats, all values of serum calcium as well as phosphorus were in normal reference range. While slight higher levels of mean serum calcium and phosphorus found in the control group of normally parturated. Mean Cortisol concentration level in six goats diagnosed with incomplete cervical dilatation as 179.17 $\pm 8.57 \mathrm{nmol} / \mathrm{l}$ which was significantly higher $(\mathrm{p}<0.05)$ than that of normally delivered goats i.e. $54.17 \pm 3.70 \mathrm{nmol} / \mathrm{l}$ (Table 2). The cortisol levels found to be significant at $5 \%$ level. The current findings are in accordance with (Strott et al., 1974) who conducted the experimental studies on the plasma Cortisol in six sheep and reported that on the day of delivery, the maternal Cortisol level was about $70 \mathrm{ng} / \mathrm{ml}$. Similar findings were also reported after performing research on the studies of Cortisol levels in goats and reported observations were as in between the range of 250-300 nmol/1 (Hydbring et al., 1999).

Table.1 Serum Concentrations of Calcium and Phosphorous (Mean \pm SE)

\begin{tabular}{|c|c|c|}
\hline No of Group & Calcium(mg/dl) & Phosphorus (mg/dl) \\
\hline Group I & $8.74 \pm 0.54$ & $6.16 \pm 0.48$ \\
\hline Group II & $9.53 \pm 0.51$ & $6.60 \pm 0.54$ \\
\hline
\end{tabular}

Table.2 Serum concentrations of Cortisol in goats $(n=12)($ Mean \pm SE)

\begin{tabular}{|c|c|c|c|}
\hline Status of Dam & Total goats & Cortisol (nmol/l) & Range \\
\hline $\begin{array}{c}\text { Incomplete cervical } \\
\text { dilatation }\end{array}$ & 6 & $179.17^{\mathbf{a}} \pm 8.57$ & $146-210$ \\
\hline Normally delivered & 6 & $54.17^{\mathbf{b}} \pm 3.70$ & $43-67$ \\
\hline
\end{tabular}

$a, b$, refer to the significant difference in between rows at 5\% level 
In contrary with the present findings (Khan and Ludri2002) after conducting a research on ten crossbred goats reported plasma concentration of Cortisol as 13.48 and 28.34 $\mathrm{ng} / \mathrm{ml}$ in two groups of single and double fetus respectively on the day of delivery. (Sarkar et al., 2007) also submitted dissimilar results of Cortisol from 10 pregnant yaks as $26.65 \pm 5.28 \mathrm{ng} / \mathrm{ml}$ on the day of parturition. (Suganya and Gomathy 2009) also observed lower findings of Cortisol levels in serum as $2.94 \pm 0.1 \mu \mathrm{g} / \mathrm{dl}$ on the day of kidding. Almost three times, increase in the Cortisol levels found in the incomplete cervical dilatation as compared to the normally delivered goats.

In summary, parturition is a very complex phenomenon and controlled by various factors. Sometimes delay in this process cause rise in maternal stress. There is no direct relation found in deficiency of serum calcium and phosphorus on comparison between incomplete dilation and normal and normally delivered goats. The levels of cortisol in the dystocia-affected goats were significantly higher and depict the stress to the animals. There is still a paucity of research on this topic. Thus, it appears that providing assistance during a difficult birth can help in reduction of the stress caused to the dam and improving the condition after delivery and preserving the future fertility of the animal.

\section{Acknowledgments}

We are thankful to Vice chancellor, Associate Dean and Head of the Department of Animal Reproduction, Gynecology and Obstetrics, MAFSU, Nagpur for providing this research opportunity.

\section{References}

Adams W and Wagner W. 1970. The role of corticoids in parturition. Biology of Reproduction 3(2): 223-228
Affan AA, Amirul FMA, Ghani AAA, Annas $S$, Zamri-Saad $M$ and Hassim $H$ A. 2018.Serum Biochemical,

Hormonal and Fatty Acid Profiles During the Late Gestation of Pregnancy Ketosis in Boer Cross Goats. JITV 23(4): 180-188

Azab M E and Abdel-Maksoud HA.1999. Changes in some hematological and biochemical parameters during prepartum and postpartum in female Baladi goats. Small Ruminant Research. 34: 77- 85

Baan M, Taverne M A M, De Gier J, Kooistra $\mathrm{H}$ S, Kindahl $\mathrm{H}$, Dieleman $\mathrm{S} \mathrm{J}$ and Okkens A C. $2008 . \quad$ Hormonal changes in spontaneous and aglepristone-induced parturition in dogs. Theriogenology. 69, 4:399407

Braun, W. B. (1997) Induced abortion in: Current Therapy in Large Animal Theriogenology.Youngquist R. S and W. R.Threlfall, 2nd ed. W. B. Saunders, Philadelphia: pp. 576-579

Fox S M, Mellor D J,Lawoko C R, Hodge H and Firth E C. 1994. Changes in plasma cortisol concentrations before, during and after analgesia, anaesthesia and anaesthesia plus ovariohysterectomy in bitches. Res Vet Sci. 57(1):110-118

Gamit K C, Rao T K S, Patel N B, Kumar N, Chaudhary S S, Solanki T H and Manat T D.2019. Blood biochemical and hormonal profiles vis-a-vis production performance of single and twin kid bearing Surti goats (Capra hircus). Indian Journal of Animal Research53,2: 270 $-274$

Hydbring, E, Madej A, MacDonald E, Drugge-Boholm G, Berglund B and Olsson K. 1999. Hormonal changes during parturition in heifers and goats are related to the phases and severity of labour. Journal of Endocrinology 160(1): $75-85$ 
Ismail B Z A, AI-Majali A M, Amireh, F and Al-Rawashdeh, O. 2008. Metabolic profiles in goat in late pregnancy with and without subclinical pregnancy toxaemia. Veterinary Clinical Pathology, 37(4): 434-437

Kamel, F M. 1988. Studies on some minerals and trace elements deficiency diseases of goats in Giza Governarates. Ph.D. thesis, Vs. Vet. Medicine, Cairo University

Khan J R and Ludri R S. 2002. Hormonal Profiles during Periparturient Period inSingle and Twin Fetus Bearing Goats. Asian-Australian Journalof Animal Science 15, 3:346-351

Liggins, G C, Fairclough R J, Grieves S A, Forster C S and Knox B S. 1977. Parturition of the Sheep. Ciba Foundation Symposium 47, 5-30

Nwe T M, Hori E, Manda M and Watanabe S. 1996. Significance of catecholamines and cortisol levels in blood during transportation stress in goats. Small Ruminant Research $20: 129 \quad-135$

Noakes, D E, Parkinson T J, EnglandG C W(2001) Arthur's Veterinary Reproduction and Obstetrics. 9th ed. Saunders, Edinburg, London: pp.213

Sarkar M, DasB C, Dutta B, Kumar V, Mohan K, Meyer H H D, Prakash B S. 2007. Application of sensitive enzymeimmuno assay for determination of cortisol in blood plasma of yaks (Poephagusgrunniens L.). General and Comparative Endocrinology 154: 85-90

Strott, Sundel and Stahlman1974. Maternal and Fetal Plasma Progesterone, Cortisol, Testosterone and 17/3Estradiol in Preparturient Sheep: Response to Fetal ACTH Infusion. Endocrinology, 95(5): 1327-39

Suganya G and Gomathy V S. 2009. Hormone profile of Tellicherry goats during periparturient period.

Tamilnadu Journal of Veterinary and Animal Science 5:211-221

Tajik J,Nazifi S and Eshtraki R. 2016. The influence of transportation stress on serum cortisol, thyroid hormones, and some serum biochemical parameters in Iranian cashmere (Raini) goat. Veterinarskiarhiv86: 795-804.

Varshney J P, Kumar G and Singh S K. 2018.Evaluation of promising biochemical markers of nutritional osteodystrophy in goats. Small Ruminant Research 169:86-89

Veronesi M C, Battocchio M, MarinelliL,Faustini M, Kindahl Hand Cairoli F.2002. Correlations among body temperature, plasma progesterone, cortisol and prostaglandin F2alpha of the periparturient bitch. Journal of Veterinary Medicine 49(5): 264-268.

\section{How to cite this article:}

Abhishek Bhardwaj, M. S. Bawaskar, S. K. Sahatpure, A. P. Gawande, G. R. Bhojne and Patil. D. V. 2020. Serum Cortisol, Calcium and Phosphorus Concentrations in Relation to Incomplete Cervical Dilatation in Goats. Int.J.Curr.Microbiol.App.Sci. 9(07): 628-632. doi: https://doi.org/10.20546/ijcmas.2020.907.071 